Scholars International Journal of Anatomy and Physiology

Abbreviated Key Title: Sch Int J Anat Physiol ISSN 2616-8618 (Print) |ISSN 2617-345X (Online) Scholars Middle East Publishers, Dubai, United Arab Emirates Journal homepage: https://saudijournals.com/sijap

Short Communication

\title{
Cystic Artery Duplication
}

Dahmane Hicham*, Omar Mkira

Ibn Sina Hospital, Mohammed V University RABAT Morocco

DOI: $10.36348 /$ sijap.2020.v03i08.004

| Received: 13.08.2020 | Accepted: 21.08.2020 | Published: 22.08 .2020

*Corresponding author: Dahmane Hicham

\section{Abstract}

We discovered during a dissection of the callot triangle during a cholecystectomy a doubling of the cystic artery, discribed being a rare variation of cystic artery.

Keywords : Cystic artery, gallbladder, cholecystectomy.

Copyright @ 2020: This is an open-access article distributed under the terms of the Creative Commons Attribution license which permits unrestricted use, distribution, and reproduction in any medium for non-commercial use (NonCommercial, or CC-BY-NC) provided the original author and source are credited.

\section{IMAGE IN CLINICAL MEDECINE}

The vascularity of the gallbladder comes from the cystic artery which divides at the neck level into two superficial and deep branches [1]. However, several variations exist. Duplication of the cystic artery can be observed in $16 \%$ of cases according to Daseler and al
[2] most often the two arteries originate from the right bronchus of the common hepatic artery. We discovered during a dissection of the callot triangle during a cholecystectomy a doubling of the cystic artery the 2 arteries were clipped and the cholecystectomy continued without any surgical difficulty.

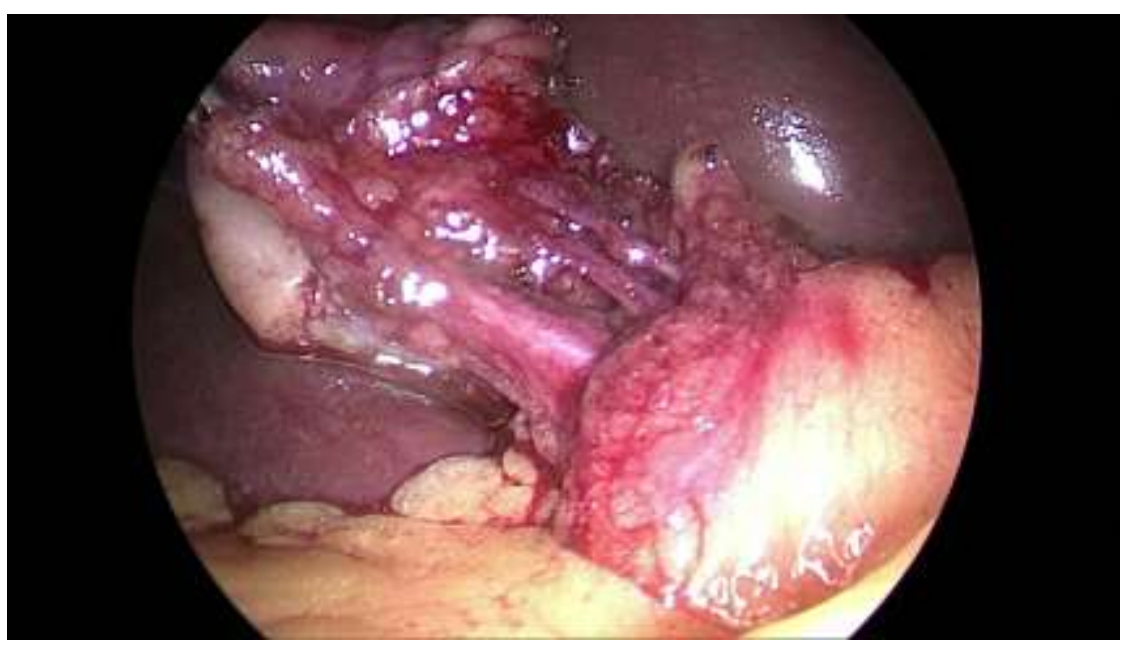

Fig-1: Opérative image

\section{REFERECNCES}

1. Castaing D, Smail A. Anatomie du foie et des voies biliaires. Encyclopédie médico-chirurgicale. 7-001A-10.
2. Daseler EH, Anson BJ. The Cystic Artery and Constituement of The Hepatic Pedicule. Surg Gyne Obst. 1947;15:1308-1312. 